\title{
PENGARUH PEMULIHAN JASA TERHADAP KEPUASAN DAN KEPERCAYAAN PELANGGAN ATAS MEREK HOTEL: STUDI PADA HOTEL BERBINTANG SATU SAMPAI TIGA DI INDONESIA
}

\author{
Michelia Tansi ${ }^{1}$, Ika Agustin ${ }^{2}$, Serli Wijaya ${ }^{3 *}$ \\ ${ }^{1,2,3}$ Fakultas Bisnis dan Ekonomi, Universitas Kristen Petra \\ Jl. Siwalankerto 121-131, Surabaya 60236 \\ Email: ${ }^{1}$ michelia.tansi@gmail.com; ${ }^{2}$ ika_agustin18@yahoo.co.id; ${ }^{3 *}$ serliw@petra.ac.id \\ *Penulis korespondensi
}

\begin{abstract}
Abstrak
Penelitian ini dilakukan untuk menganalisa penerapan pemulihan jasa di hotel berbintang satu sampai tiga di Indonesia atas kegagalan jasa yang terjadi dan pengaruhnya terhadap kepercayaan pelanggan atas merek hotel. Survei dilakukan kepada 286 responden yang menginap di hotel dan melakukan keluhan akibat kegagalan jasa yang dialami selama menginap. Data primer diolah dengan teknik statistik SEM-PLS. Hasil penelitian menunjukkan bahwa pemulihan jasa memiliki pengaruh yang positif terhadap kepuasan atas pemulihan jasa. Sementara itu, kepuasan atas pemulihan jasa terbukti memiliki pengaruh yang positif dan signifikan dalam mengembalikan kepercayaan responden atas merek hotel serta menjadi variabel mediasi yang signifikan bagi hubungan antara kepuasan atas pemulihan jasa dan kepercayaan merek.
\end{abstract}

Kata kunci: Kegagalan jasa, pemulihan jasa, kepercayaan merek, kepuasan, hotel.

\begin{abstract}
This study was conducted to determine the impact of service recovery (perceived justice) at one to three star-rated hotels in Indonesia towards brand trust and satisfaction of service recovery. Survey to 286 respondents was completed to those who have stayed at hotels and complained about the service failure they experienced during their stay. SEM-PLS was utilised to analyse the relationships among the examined variables. The results shows that service recovery has a positive and significant effect on service recovery's satisfaction. Further, service recovery's satisfaction also poses a positive and significant influence on brand trust and play a significant mediating variable for the association between service recovery and brand trust.
\end{abstract}

Keywords: Service failure, service recovery, brand trust, satisfaction, perceived justice, hotel.

\section{PENDAHULUAN}

Industri perhotelan menjadi salah satu industri yang berkembang amat cepat di Indonesia khususnya di kota-kota besar. Data dari Biro Pusat Statistik Indonesia menunjukkan bahwa jumlah hotel berbintang pada tahun 2016 bertambah sebanyak 190 usaha atau meningkat sekitar 8,65 persen dibandingkan dengan tahun 2015. Pada tahun 2016 jumlah hotel berbintang yang terbanyak adalah hotel bintang tiga, yaitu 839 usaha (35,15 persen) dengan 72.951 kamar (31,31 persen) diikuti hotel bintang dua sebanyak 528 usaha (22,12 persen) dengan jumlah kamar sebanyak 34.596 (14,85 persen). Di urutan ke tiga hotel bintang empat sebanyak 453 hotel (18,98 persen) dengan jumlah kamar 68.425 buah (29,37 persen) (Badan Pusat Statistik, 2016).

Perkembangan bisnis hotel yang demikian pesat di Indonesia membuat persaingan tidak bisa dihindari.
Oleh karena itu, hotel-hotel harus dapat mempertahankan kualitas dan meminimalisir kesalahan pada jasa. Meskipun perusahaan yang sudah memiliki sistem terbaik masih tidak dapat luput dari kesalahan (Kim, Yoo dan Lee, 2011). Namun, sebaik-baiknya kualitas jasa yang diberikan, kesalahan dapat terjadi dalam proses penyampaian jasa tersebut dimana menurut Babakus, Emin, Yavas, Karatepee dan Avici (2003) disebut sebagai kegagalan jasa atau service failure. Lovelock dan Wright (2005) mendefinisikan kegagalan jasa merupakan persepsi konsumen bahwa satu aspek tertentu atau lebih dalam penyerahan jasa tidak memenuhi harapan konsumen. Karena jasa bersifat intangible, kegagalan jasa tidak dapat diperbaiki dengan cepat, kualitas jasa sendiri berubahubah berdasarkan manusia yang memberikan layanan tidak seperti barang yang tangible yang sudah memiliki ketetapan standar (de Ruyter and Wetzels, 2000). 
Untuk mengatasi kegagalan jasa (service failure) yang telah terjadi, perusahaan biasanya melakukan pemulihan jasa (service recovery) kepada konsumen. Lewis dan Sotiris (2001) mendefinisikan pemulihan jasa (service recovery) sebagai sebuah hasil pemikiran, rencana, dan proses untuk menebus kekecewaan konsumen menjadi lebih puas terhadap organisasi setelah jasa yang diberikan mengalami masalah (kegagalan). Melalui sistem pemulihan jasa inilah hotel berharap dapat menebus kekecewaan konsumen yang dikarenakan gagalnya jasa atau gagalnya penepatan janji yang diberikan perusahaan. Menurut Barnes (2003), secara umum service recovery dapat diwujudkan dengan tiga cara utama yaitu dengan distributive justice, procedural justice dan interactional justice.

Dari penelitian sebelumnya oleh Kau dan Loh (2006), pemulihan jasa yang dilakukan oleh perusahaan terbukti berpengaruh secara signifikan dan positif terhadap kepuasan konsumen. Kepuasan adalah tanggapan yang berpusat pada pelayanan yang baik, dievaluasi pada saat atau setelah melakukan konsumsi, baik konsumsi sekarang atau sebelumnya dengan respon yang baik. (Oliver, 1999). Kepuasan yang ada pada konsumen memiliki keterkaitan yang kuat terhadap kepercayaan konsumen pada perusahaan (Belaid dan Behi, 2011). Kepercayaan merek (brand trust) adalah keinginan untuk bergantung pada sebuah merek, berdasarkan kepercayaan, meskipun terdapat ketidakpastian atau resiko yang ada pada merek tersebut (Becerra dan Badrinarayanan, 2013). Delgado, Munuera dan Yague (2003) memaparkan bahwa kepercayaan merek memiliki dua komponen yaitu brand reliability yang artinya nilai merek yang dijanjikan perusahaan pada konsumen dapat dilaksanakan sesuai dengan yang diharapkan konsumen, sehingga konsumen puas karena merek tersebut memenuhi janjinya kepada konsumen. Komponen kedua adalah brand intention yang merupakan kepercayaan konsumen terhadap merek bahwa sebuah merek mampu menjaga kepercayaan konsumen meskipun suatu saat merek tersebut menghadapi masalah yang tidak terduga (contohnya: ketika McDonald's menghadapi masalah penyakit sapi gila di Eropa tahun 2001).

Dalam studi ini, peneliti ingin mengkaji lebih dalam mengenai bagaimana pemulihan jasa dapat mempengaruhi kepercayaan tamu atas merek hotel dimana tamu menginap. Selain itu, peneliti juga ingin mengetahui seberapa baik standar pemulihan jasa yang sudah diimplementasikan hotel berbintang satu sampai tiga di Indonesia. Apabila dibandingkan dengan hotel berbintang empat dan lima, maka standard operating procedures yang dimiliki hotel berbintang satu sampai tiga dapat dikatakan masih kurang terstandarisasi. Dengan demikian, informasi dari penelitian ini diharapkan dapat memberikan masukan bagi pihak manajemen hotel untuk menambah daya saing hotel berbintang satu-tiga di Indonesia.

\section{TINJAUAN PUSTAKA}

\section{Kegagalan Jasa dan Pemulihan Jasa}

Menurut Lovelock dan Wright (2005) kegagalan jasa adalah persepsi konsumen bahwa satu aspek tertentu atau lebih dalam penyerahan jasa tidak memenuhi harapan konsumen. Kim, Yoo, dan Lee (2011) menyatakan kegagalan jasa adalah suatu kecelakaan atau masalah yang terjadi pada saat penyampaian jasa kepada konsumen di suatu perusahaan. Konsep pemulihan jasa (service recovery) merujuk pada tindakan yang diambil oleh perusahaan ketika mengalami kegagalan jasa (Baghetstan et al., 2012). Sementara itu, Lewis dan Spyrakopulos (2001) mendefinisikan pemulihan jasa sebagai tindakan spesifik yang dilakukan untuk memastikan bahwa pelanggan mendapatkan tingkat pelayanan yang pantas setelah terjadi masalah-masalah dalam pelayanan secara normal. Adapun bentuk-bentuk pemulihan jasa secara umum menurut Kau dan Loh (2006) dapat dikelompokkan ke dalam tiga bentuk keadilan yang dipersepsikan konsumen (perceived justice), yakni:

1) Distributive Justice, yaitu bentuk pemulihan jasa yang berfokus pada hasil dari penyelesaian pemulihan jasa, misalnya usaha apa yang dilakukan perusahaan untuk menangani keluhan konsumen ketika perusahaan melakukan kesalahan, meskipun perusahaan harus mengeluarkan biaya yang besar sebagai pengganti kerugian.

2) Procedural justice, adalah bentuk pemulihan jasa yang berfokus pada keadilan yang seharusnya diterima oleh konsumen ketika mengajukan keluhan sesuai dengan aturan dan kebijakan yang telah ditetapkan atau dibuat oleh perusahaan.

3) Interactional Justice, adalah bentuk pemulihan jasa yang berfokus pada prilaku atau respon yang ditujukan oleh pihak perusahaan ketika berhadapan dengan konsumen yang mengajukan komplain.

\section{Kepuasan}

Kepuasan adalah tanggapan yang berpusat pada pelayanan yang baik, dievaluasi pada saat atau setelah melakukan konsumsi, baik konsumsi sekarang maupun sebelumnnya dengan respon yang baik (Oliver 
1999). Menurut Komunda dan Osarenkhoe (2012) kepuasan adalah hasil evaluasi dari produk dan jasa yang diterima oleh konsumen. Kepuasan konsumen bergantung pada perasaan dan perilaku konsumen setelah mengalami proses konsumsi jasa atau pemulihan jasa (Boshoff, 2005; Jamal and Naser, 2002).

\section{Kepercayaan Merek}

Menurut Delgado et al., (2003), kepercayaan merek (brand trust) adalah kemampuan merek untuk dapat dipercaya (brand reliability). Reliabilitas merek bersumber pada keyakinan konsumen bahwa produk tersebut mampu memenuhi nilai yang dijanjikan dan brand intention yang didasarkan pada keyakinan konsumen bahwa merek tersebut mampu mengutamakan kepentingan konsumen.

\section{Hubungan Antara Konsep dan Perumusan Hipotesis}

Dalam pemulihan jasa digunakan teori keadilan untuk memprediksi puas atau tidaknya seorang konsumen setelah mengalami kegagalan jasa (Kim et al., 2011). Dalam penelitian yang dilakukan oleh Cheung dan To (2016), ditemukan bahwa kebijakan perusahaan dalam melakukan pemulihan jasa menentukan kepuasan konsumennya. Kepuasan konsumen juga dapat diperoleh ketika konsumen tersebut menerima pemulihan jasa lebih dari ekspektasinya. Cheung et al., (2016), menyatakan bahwa efektivitas dalam pemulihan jasa untuk memecahkan masalah kegagalan jasa tergantung pada perceived justice yang terdiri dari distributive justice, procedural justice, dan interactional justice. Distributive justice berfokus pada pengalokasian biaya dan manfaat untuk mencapai kesetaraan ekspektasi konsumen terhadap perusahaan (Kim et al., 2011), pengalokasian biaya tersebut diwujudkan dalam bentuk barang (Cheung at al., 2016). Procedural justice adalah keadilan dalam pemulihan jasa yang diwujudkan dalam kebijakan, prosedur, dan sebagai alat untuk bernegosiasi. Interactional justice adalah pemulihan jasa yang diterima konsumen melalui komunikasi dan empati secara personal. Meskipun tiga dimensi di atas merupakan komponen yang individu, tetapi ketiga hal tersebut saling berkaitan satu sama lain dalam menentukan perilaku konsumen terhadap persepsinya dalam pemulihan jasa. Dari penelitian sebelumnya menyatakan bahwa tiga komponen diatas memiliki dampak yang positif dalam kepuasaan pemulihan jasa (Kim et al., 2011). Dari kajian literatur di atas, peneliti merumuskan hipotesis sebagai berikut:

$\mathrm{H}_{1}$ : Pemulihan jasa mempengaruhi kepuasan atas pemulihan jasa secara signifikan
$\mathrm{H}_{1 \mathrm{a}}$ : Distributive justice mempengaruhi kepuasan konsumen secara signifikan

$\mathrm{H}_{\mathrm{lb}}$ : Procedural justice mempengaruhi kepuasan konsumen secara signifikan

$\mathrm{H}_{1 \mathrm{c}}$ : Interactional justice mempengaruhi kepuasan konsumen secara signifikan

Kepuasan konsumen menjadi prioritas bagi keberlanjutan bisnis (Veloutsou, 2015). Ketika pemulihan jasa yang diberikan melebihi ekspektasi konsumen akibat kegagalan jasa yang dialami, maka konsumen akan merasa puas dengan tindakan pemulihan layanan yang ada. Contohnya apabila konsumen menerima diskon atau refund (Cheung et al., 2016). Kepuasan adalah pemenuhan ekspektasi dari jasa pada saat mengkonsumsi jasa maupun setelah mengkonsumsi jasa (Veloutsou, 2015). Untuk detail penelitian yang dilakukan oleh Veloutsou (2015) tingkat kepuasan dari pengalaman konsumen terhadap perusahaan akan mempengaruhi perkembangan hubungan antara konsumen dengan perusahaan. Hubungan konsumen dengan perusahaan yang baik akan terjadi jika konsumen puas. Kepercayaan dapat membangun komitmen terutama membangun hubungan dengan merek perusahaan. Kepercayaan merek oleh konsumen dapat diukur dengan dua indikator yakni: brand reliability dan brand intention (Delgado et al., 2003). Dalam penelitian Delgado et al., (2003) brand reliability dimaknai sebagai sebuah merek yang dapat diandalkan dan dipercaya oleh konsumen. Sedangkan, brand intention adalah kondisi ketika konsumen percaya, konsumen memiliki niat untuk kembali pada merek tersebut. Dari kajian literatur di atas, peneliti merumuskan hipotesis sebagai berikut:

$\mathrm{H}_{2}$ : Kepuasan atas pemulihan jasa memiliki pengaruh yang signifikan terhadap kepercayaan merek.

$\mathrm{H}_{2 \mathrm{a}}$ : Kepuasan atas pemulihan jasa memiliki pengaruh yang signifikan terhadap brand reliability.

$\mathrm{H}_{2 b}$ : Kepuasan atas pemulihan jasa memiliki pengaruh yang signifikan terhadap brand intention.

$\mathrm{H}_{3}$ : Kepuasan atas pemulihan jasa sebagai variabel mediasi memperkuat hubungan antara pemulihan jasa terhadap kepercayaan merek.

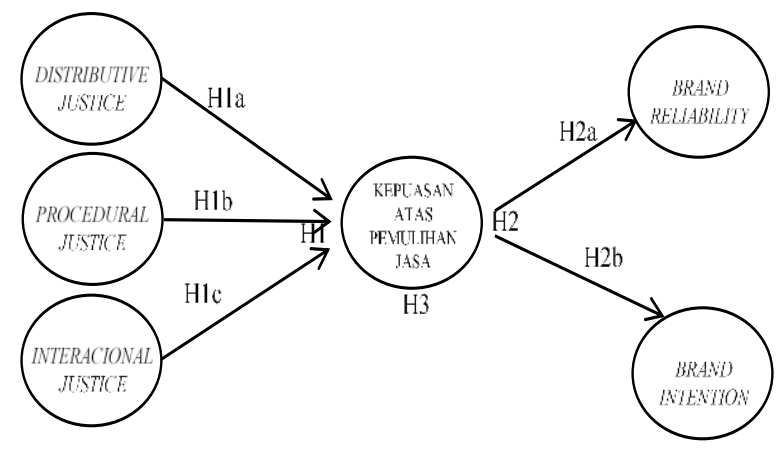

Gambar 1. Model Penelitian 


\section{METODE PENELITIAN}

Penelitian ini menggunakan pendekatan kuantitatif kausal. Dalam penelitian ini peneliti mengukur hubungan sebab akibat antara variabel independen yaitu pemulihan jasa: distributive justice, procedural justice dan interactional justice yang mempengaruhi variabel dependen yaitu brand reliability dan brand intention dengan kepuasan atas pemulihan jasa sebagai variabel mediatingning. Pengambilan sampel dilakukan secara purposive sampling dengan tiga kriteria sebagai berikut: 1) responden merupakan tamu hotel yang pernah menginap di salah satu dari hotel berbintang satu, dua, atau tiga di Indonesia; 2) selama kurun waktu menginap, responden mengalami kegagalan jasa dari pihak hotel; dan 3) responden melaporkan kegagalan jasa yang dialami kepada pihak hotel dan mendapatkan pemulihan jasa. Data primer dalam penelitian ini diolah dengan teknik statistik SEM-PLS. Seluruh variabel dan indikator pengukuran variabel telah memenuhi uji validitas dan reliabilitas.

\section{HASIL PENELITIAN DAN PEMBAHASAN}

\section{Profil Demografis}

Total responden yang berpartisipasi dalam survei sebanyak 286 orang. Dari jumlah ini, total kuisioner yang siap diolah sebesar 198 sehingga response rate sebesar $69.23 \%$. Responden didominasi oleh pria dengan rentang usia 25 - 34 tahun. Sebagian besar responden bekerja sebagai pegawai swasta dengan rata-rata pendapatan per-bulan antara Rp. 3.000.000,0 - Rp. 4.999.999,-

Tabel 1. Profil Demografis

\begin{tabular}{|c|c|c|c|}
\hline & Atribut Demografis & $\mathbf{n}$ & $\%$ \\
\hline \multicolumn{4}{|c|}{ Jenis Kelamin } \\
\hline & 1.Pria & 106 & $53.53 \%$ \\
\hline & 2. Wanita & 92 & $46.47 \%$ \\
\hline \multicolumn{4}{|l|}{ Usia } \\
\hline & $1.18-24$ tahun & 99 & $50.00 \%$ \\
\hline & 2.25 - 34 tahun & 79 & $39.90 \%$ \\
\hline & 3.Lebih dari 35 tahun & 20 & $10.10 \%$ \\
\hline \multicolumn{4}{|l|}{ Pekerjaan } \\
\hline & 1.Swasta & 68 & $34.35 \%$ \\
\hline & 2.Wiraswasta & 42 & $21.21 \%$ \\
\hline & 3.Pelajar / Mahasiswa & 64 & $32.32 \%$ \\
\hline & 4.Lainnya & 24 & $12.12 \%$ \\
\hline \multicolumn{4}{|c|}{ Pendapatan rata - rata per bulan } \\
\hline & 1.Dibawah Rp, 2.999.999,- & 42 & $21.21 \%$ \\
\hline & 2.Rp, 3.000.000,- - Rp, 4.999.999,-- & 61 & $30.81 \%$ \\
\hline & 3.Rp, 5.000.000,- - Rp, 6.999.000,- & 57 & $28.79 \%$ \\
\hline & 4.Lebih dari Rp, 7.000.000,-- & 38 & $19.19 \%$ \\
\hline
\end{tabular}

Tabel 2. Penilaian Responden dengan Tingkat Kesetujuan atas Pemulihan Jasa terhadap Kegagalan Jasa

\begin{tabular}{|c|c|c|c|c|}
\hline No & Peryataan & $\begin{array}{c}\text { Rata - } \\
\text { Rata }\end{array}$ & $\begin{array}{l}\text { Standar } \\
\text { Deviasi }\end{array}$ & $\begin{array}{l}\text { Kete- } \\
\text { rangan }\end{array}$ \\
\hline \multicolumn{5}{|c|}{ Distributive Justice } \\
\hline & $\begin{array}{l}\text { Pihak hotel memberikan ganti } \\
\text { rugi berupa sejumlah uang atas } \\
\text { kerugian yang dialami. }\end{array}$ & 5.11 & 1.63 & Setuju \\
\hline & $\begin{array}{l}\text { Pihak hotel memberikan } \\
\text { potongan harga/diskon atas } \\
\text { kegagalan jasa sebagai bentuk } \\
\text { kompensasi terhadap kerugian } \\
\text { yang dialami. }\end{array}$ & 5.26 & 1.49 & Setuju \\
\hline & $\begin{array}{l}\text { Pihak hotel memberikan } \\
\text { voucher sebagai kompensasi } \\
\text { atas kegagalan jasa yang } \\
\text { dialami. }\end{array}$ & 5.22 & 1.48 & Setuju \\
\hline & $\begin{array}{l}\text { Pihak hotel memberikan produk } \\
\text { secara cuma-cuma sebagai } \\
\text { bentuk ganti rugi. }\end{array}$ & 5.28 & 1.52 & Setuju \\
\hline & $\begin{array}{l}\text { Pihak hotel memindahkan ke } \\
\text { kamar yang sesuai standar } \\
\text { bahkan yang lebih baik } \\
\text { (upgrade) ketika kamar yang } \\
\text { ditempati semula tidak sesuai } \\
\text { dengan standar. }\end{array}$ & 5.75 & 1.24 & $\begin{array}{l}\text { Sangat } \\
\text { Setuju }\end{array}$ \\
\hline $\begin{array}{l}\text { Rat } \\
\text { Just }\end{array}$ & $\begin{array}{l}\text { a-Rata Perceived Distributive } \\
\text { tice }\end{array}$ & 5.32 & 1.47 & $\begin{array}{l}\text { Sangat } \\
\text { Setuju }\end{array}$ \\
\hline \multicolumn{5}{|c|}{ Procedural Justice } \\
\hline & $\begin{array}{l}\text { Pihak hotel tidak berbelit-belit } \\
\text { dalam menangani masalah. }\end{array}$ & 5.52 & 1.24 & $\begin{array}{l}\text { Sangat } \\
\text { Setuju }\end{array}$ \\
\hline & $\begin{array}{l}\text { Pihak hotel melakukan } \\
\text { pengambilan keputusan yang } \\
\text { tepat dalam menangani keluhan } \\
\text { yang disampaikan. }\end{array}$ & 5.60 & 1.13 & $\begin{array}{l}\text { Sangat } \\
\text { Setuju }\end{array}$ \\
\hline & $\begin{array}{l}\text { Pihak hotel memberikan akses } \\
\text { yang mudah untuk } \\
\text { menyampaikan keluhan. }\end{array}$ & 5.66 & 1.09 & $\begin{array}{l}\text { Sangat } \\
\text { Setuju }\end{array}$ \\
\hline & $\begin{array}{l}\text { Pihak hotel menyelesaikan } \\
\text { masalah dengan cepat. }\end{array}$ & 5.64 & 1.10 & $\begin{array}{l}\text { Sangat } \\
\text { Setuju }\end{array}$ \\
\hline & $\begin{array}{l}\text { Pihak hotel menyelesaikan } \\
\text { masalah dengan tepat. }\end{array}$ & 5.67 & 1.10 & $\begin{array}{l}\text { Sangat } \\
\text { Setuju }\end{array}$ \\
\hline & $\begin{array}{l}\text { Pihak hotel menangani keluhan } \\
\text { dengan fleksibel dan tidak } \\
\text { terpaku pada sistem perusahaan. }\end{array}$ & 5.57 & 1.18 & $\begin{array}{l}\text { Sangat } \\
\text { Setuju }\end{array}$ \\
\hline & $\begin{array}{l}\text { Pihak hotel mau } \\
\text { mempertimbangakan saran } \\
\text { yang diberikan. }\end{array}$ & 5.57 & 1.24 & $\begin{array}{l}\text { Sangat } \\
\text { Setuju }\end{array}$ \\
\hline & $\begin{array}{l}\text { a-Rata Perceived Procedural } \\
\text { tice }\end{array}$ & 5.61 & 1.16 & $\begin{array}{l}\text { Sangat } \\
\text { Setuju }\end{array}$ \\
\hline \multicolumn{5}{|c|}{ Interactional Justice } \\
\hline & $\begin{array}{l}\text { Pihak hotel memberikan } \\
\text { penjelasan yang baik dan logis } \\
\text { terhadap keluhan yang } \\
\text { disampaikan. }\end{array}$ & 5.67 & 1.04 & $\begin{array}{l}\text { Sangat } \\
\text { Setuju }\end{array}$ \\
\hline & $\begin{array}{l}\text { Pihak hotel mau dengan jujur } \\
\text { mengakui kesalahan dan } \\
\text { meminta maaf. }\end{array}$ & 5.66 & 1.15 & $\begin{array}{l}\text { Sangat } \\
\text { Setuju }\end{array}$ \\
\hline & $\begin{array}{l}\text { Pihak hotel bersikap sopan saat } \\
\text { menangani keluhan. }\end{array}$ & 5.77 & 1.02 & $\begin{array}{l}\text { Sangat } \\
\text { Setuju }\end{array}$ \\
\hline & $\begin{array}{l}\text { Pihak hotel berusaha sebaik } \\
\text { mungkin (optimal) dalam } \\
\text { menangani keluhan yang } \\
\text { disampaikan. }\end{array}$ & 5.78 & 1.05 & $\begin{array}{l}\text { Sangat } \\
\text { Setuju }\end{array}$ \\
\hline
\end{tabular}




\begin{tabular}{lccc}
\hline No $\quad$ Peryataan & $\begin{array}{c}\text { Rata - } \\
\text { Rata }\end{array}$ & $\begin{array}{c}\text { Standar } \\
\text { Deviasi }\end{array}$ & $\begin{array}{c}\text { Kete- } \\
\text { rangan }\end{array}$ \\
\hline 5 Pihak hotel mendengarkan \\
$\begin{array}{l}\text { dengan baik keluhan yang } \\
\text { disampaikan. }\end{array}$ & 5.80 & 1.09 & $\begin{array}{l}\text { Sangat } \\
\text { Setuju }\end{array}$ \\
6 Pihak hotel mencoba untuk \\
$\begin{array}{l}\text { memahami masalah yang } \\
\text { sedang dialami. }\end{array}$ & 5.72 & 1.00 & $\begin{array}{l}\text { Sangat } \\
\text { Setuju }\end{array}$ \\
$\begin{array}{l}\text { Rata-Rata Perceived Interactional } \\
\text { Justice }\end{array}$ & 5.72 & 1.06 & $\begin{array}{l}\text { Sangat } \\
\text { Setuju }\end{array}$ \\
\hline
\end{tabular}

Tabel 3. Penilaian Responden terhadap Tingkat Kesetujuan Kepuasan atas Pemulihan Jasa yang Mengembalikan Kepercayaan Merek

\begin{tabular}{|c|c|c|c|c|}
\hline No & Peryataan & $\begin{array}{c}\text { Rata } \\
\text { rata }\end{array}$ & $\begin{array}{l}\text { Standar } \\
\text { Deviasi }\end{array}$ & $\begin{array}{c}\text { Keterang- } \\
\text { an }\end{array}$ \\
\hline \multicolumn{5}{|c|}{ Kepuasan atas Pemulihan Jasa } \\
\hline 1 & $\begin{array}{l}\text { Puas dengan tanggapan yang } \\
\text { hotel berikan atas masalah. }\end{array}$ & 5.58 & 1.09 & $\begin{array}{l}\text { Sangat } \\
\text { Setuju }\end{array}$ \\
\hline 2 & $\begin{array}{l}\text { Puas dengan cara hotel } \\
\text { memecahkan masalah. }\end{array}$ & 5.67 & 1.08 & $\begin{array}{l}\text { Sangat } \\
\text { Setuju }\end{array}$ \\
\hline 3 & $\begin{array}{l}\text { Puas dengan perlakuan } \\
\text { karyawan yang terlibat dalam } \\
\text { memecahkan masalah yang } \\
\text { dialami. }\end{array}$ & 5.56 & 1.11 & $\begin{array}{l}\text { Sangat } \\
\text { Setuju }\end{array}$ \\
\hline 4 & $\begin{array}{l}\text { Puas dengan prosedur yang } \\
\text { diterapkan hotel untuk } \\
\text { menyelesaikan masalah. }\end{array}$ & 5.52 & 1.10 & $\begin{array}{l}\text { Sangat } \\
\text { Setuju }\end{array}$ \\
\hline 5 & $\begin{array}{l}\text { Puas dengan solusi yang } \\
\text { diberikan atas masalah yang } \\
\text { dialami. }\end{array}$ & 5.57 & 1.05 & $\begin{array}{l}\text { Sangat } \\
\text { Setuju }\end{array}$ \\
\hline 6 & $\begin{array}{l}\text { Saya puas dengan kompensasi } \\
\text { yang saya terima. }\end{array}$ & 5.59 & 1.12 & $\begin{array}{l}\text { Sangat } \\
\text { Setuju }\end{array}$ \\
\hline & Total Rata-Rata & 5.58 & 1.00 & $\begin{array}{l}\text { Sangat } \\
\text { Setuju }\end{array}$ \\
\hline \multicolumn{5}{|c|}{ Brand Reliability } \\
\hline & $\begin{array}{l}\text { Pihak hotel memenuhi } \\
\text { ekspektasi pemulihan jasa yang } \\
\text { diharapkan. }\end{array}$ & 5.63 & 1.00 & $\begin{array}{l}\text { Sangat } \\
\text { Setuju }\end{array}$ \\
\hline 2 & $\begin{array}{l}\text { Merasa percaya diri ketika } \\
\text { menginap di hotel. }\end{array}$ & 5.61 & 1.14 & $\begin{array}{l}\text { Sangat } \\
\text { Setuju }\end{array}$ \\
\hline 3 & $\begin{array}{l}\text { Merasa tidak dikecewakan atas } \\
\text { pemulihan jasa yang diberikan } \\
\text { oleh pihak hotel. }\end{array}$ & 5.59 & 1.14 & $\begin{array}{l}\text { Sangat } \\
\text { Setuju }\end{array}$ \\
\hline 4 & $\begin{array}{l}\text { Pihak hotel menjamin dapat } \\
\text { menyelesaikan masalah yang } \\
\text { dialami. }\end{array}$ & 5.60 & 1.03 & $\begin{array}{l}\text { Sangat } \\
\text { Setuju }\end{array}$ \\
\hline & Total Rata-Rata & 5.61 & 1.08 & $\begin{array}{l}\text { Sangat } \\
\text { Setuju }\end{array}$ \\
\hline \multicolumn{5}{|c|}{ Brand Intention } \\
\hline & $\begin{array}{l}\text { Ada kejujuran dan ketulusan } \\
\text { hotel dalam melakukan } \\
\text { pemulihan jasa. }\end{array}$ & 5.68 & 1.05 & $\begin{array}{l}\text { Sangat } \\
\text { Setuju }\end{array}$ \\
\hline 2 & $\begin{array}{l}\text { Rasa percaya terhadap } \\
\text { penyelesaian masalah yang } \\
\text { diberikan oleh pihak hotel. }\end{array}$ & 5.65 & 1.02 & $\begin{array}{l}\text { Sangat } \\
\text { Setuju }\end{array}$ \\
\hline 3 & $\begin{array}{l}\text { Pihak hotel mengusahakan } \\
\text { kepuasan terhadap pemulihan } \\
\text { jasa yang diterima. }\end{array}$ & 5.73 & 1.04 & $\begin{array}{l}\text { Sangat } \\
\text { Setuju }\end{array}$ \\
\hline \multirow[t]{2}{*}{4} & $\begin{array}{l}\text { Pihak hotel mengganti kerugian } \\
\text { saya sesuai dengan yang } \\
\text { diharapkan. }\end{array}$ & 5.56 & 1.11 & $\begin{array}{l}\text { Sangat } \\
\text { Setuju }\end{array}$ \\
\hline & Total Rata-Rata & 5.66 & 1.06 & $\begin{array}{l}\text { Sangat } \\
\text { Setuju }\end{array}$ \\
\hline
\end{tabular}

\section{Tahap 1: Pengujian Outer Model}

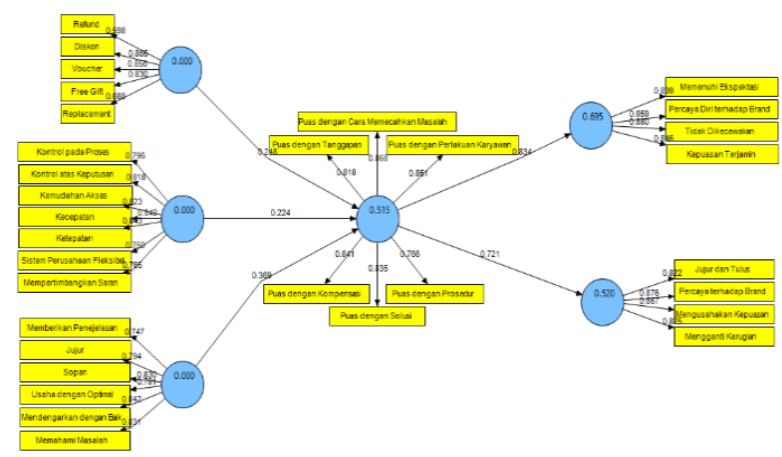

Gambar 2. Hasil Uji Validitas Konvergen

Tabel 4 memuat hasil uji validitas konvergen dimana dapat dilihat bahwa seluruh indikator memiliki nilai loading lebih besar dari 0.5 yang berati memenuhi syarat validitas konvergen. Oleh karena itu, dapat dikatakan keseluruhan indikator dapat digunakan dalam penghitungan untuk penelitian ini.

Tabel 4. Hasil Uji Validitas Konvergen

\begin{tabular}{|c|c|c|c|}
\hline Variabel & Indikator & $\begin{array}{c}\text { Skor } \\
\text { Loading }\end{array}$ & $\begin{array}{l}\text { Kete- } \\
\text { rangan }\end{array}$ \\
\hline Distributive & Refund & 0.598 & Valid \\
\hline \multirow[t]{4}{*}{ Justice } & Diskon & 0.865 & Valid \\
\hline & Voucher & 0.856 & Valid \\
\hline & Free Gift & 0.830 & Valid \\
\hline & Replacement & 0.688 & Valid \\
\hline \multirow{7}{*}{$\begin{array}{l}\text { Procedural } \\
\text { Justice }\end{array}$} & Kontrol pada proses & 0.796 & Valid \\
\hline & Kontrol atas keputusan & 0.818 & Valid \\
\hline & Kemudahan akses & 0.823 & Valid \\
\hline & Kecepatan & 0.842 & Valid \\
\hline & Ketepatan & 0.843 & Valid \\
\hline & Sistem perusahaan fleksibel & 0.750 & Valid \\
\hline & Mempertimbangkan saran & 0.765 & Valid \\
\hline \multirow{6}{*}{$\begin{array}{l}\text { Interactional } \\
\text { Justice }\end{array}$} & Memberikan Penjelasan & 0.747 & Valid \\
\hline & Jujur & 0.794 & Valid \\
\hline & Sopan & 0.830 & Valid \\
\hline & Usaha dengan optimal & 0.781 & Valid \\
\hline & Mendengarkan dengan baik & 0.842 & Valid \\
\hline & Memahami masalah & 0.831 & Valid \\
\hline Kepuasan atas & $\begin{array}{l}\text { Puas dengan Cara } \\
\text { menanggapi }\end{array}$ & 0.818 & Valid \\
\hline \multirow[t]{5}{*}{ Pemulihan Jasa } & $\begin{array}{l}\text { Puas dengan Cara } \\
\text { memecahkan masalah }\end{array}$ & 0.868 & Valid \\
\hline & $\begin{array}{l}\text { Puas dengan Perlakuan } \\
\text { karyawan }\end{array}$ & 0.851 & Valid \\
\hline & Puas dengan kompensasi & 0.841 & Valid \\
\hline & Puas dengan solusi & 0.835 & Valid \\
\hline & Puas dengan prosedur & 0.766 & Valid \\
\hline \multirow[t]{4}{*}{ Brand Reliability } & yMemenuhi ekspektasi & 0.889 & Valid \\
\hline & Percaya diri terhadap brand & 0.859 & Valid \\
\hline & Tidak dikecewakan & 0.880 & Valid \\
\hline & Kepuasan terjamin & 0.846 & Valid \\
\hline \multirow[t]{4}{*}{ Brand Intention } & Jujur dan tulus & 0.822 & Valid \\
\hline & Percaya terhadap brand & 0.876 & Valid \\
\hline & Mengusahakan kepuasan & 0.867 & Valid \\
\hline & Mengganti kerugian & 0.825 & Valid \\
\hline
\end{tabular}


Selanjutnya, hasil uji validitas diskriminan ditunjukkan pada Tabel 5 dimana terlihat bahwa semua indikator yang ada telah memenuhi syarat discriminant validity karena memiliki nilai cross loading terbesar untuk variabel yang dibentuknya dan tidak pada variabel lain.

Tabel 5. Hasil Uji Nilai Cross-Loading untuk Uji Validitas Diskriminan

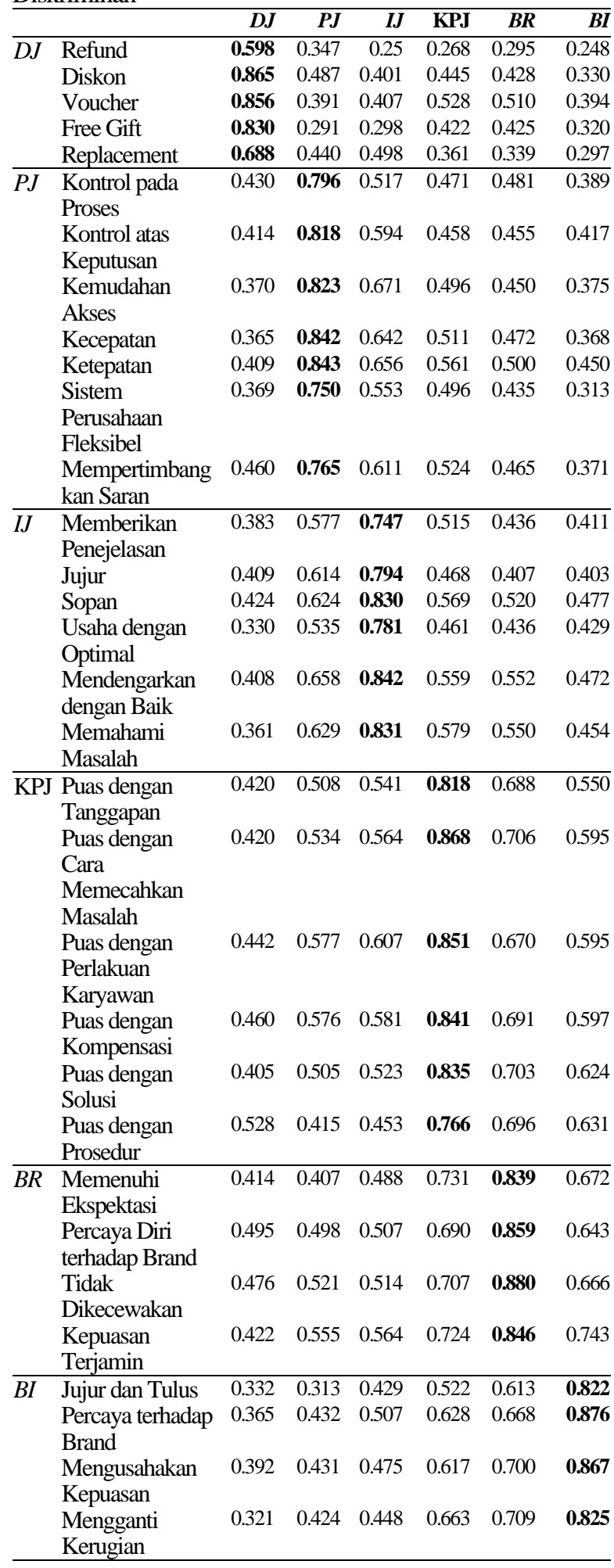

\section{Tahap 2: Pengujian Inner Model}

Nilai koefisien determinasi $\left(\mathrm{R}^{2}\right)$ menunjukkan kemampuan variabel laten independen dalam menjelasan perubahan variabel laten dependen (Abdillah \& Djogiyanto, 2015). Berikut ini adalah hasil perhitungan $\mathrm{R}^{2}$ :

Tabel 6. Hasil $R$-square $\left(\mathrm{R}^{2}\right)$

\begin{tabular}{lc}
\hline \multicolumn{1}{c}{ Variabel } & Nilai $\boldsymbol{R}$-square $\left(\boldsymbol{R}^{2}\right)$ \\
\hline Kepuasan atas Pemulihan Jasa & 0.515 \\
Brand Reliability & 0.695 \\
Brand Intention & 0.520 \\
\hline
\end{tabular}

Tabel 6 menunjukkan bahwa nilai $\mathrm{R}^{2}$ kepuasan atas pemulihan jasa sebesar 0.515 , yang berarti variabel mediasi (kepuasan atas pemulihan jasa) dapat dijelaskan oleh ketiga variabel dependen (distributive justice, procedural justice dan interactional justice) sebesar $51.5 \%$, sedangkan $48.5 \%$ lainnya dijelaskan oleh variabel lainnya diluar yang dijelaskan oleh peneliti. Sementara itu nilai $\mathrm{R}^{2}$ untuk variabel brand reliability adalah sebesar 0.695 yang berarti variabel brand reliability dapat dijelaskan oleh variabel kepuasan atas pemulihan jasa sebesar $69.5 \%$, sedangkan $30.5 \%$ lainnya dijelaskan oleh variabel lainnya diluar yang dijelaskan oleh peneliti. Sementara itu, nilai $\mathrm{R}^{2}$ untuk variabel brand intention adalah sebesar 0.520 yang berarti variabel brand intention dapat dijelaskan oleh variabel kepuasan atas pemulihan jasa sebesar $52 \%$, sedangkan $48 \%$ lainnya dijelaskan oleh variabel lainnya diluar yang dijelaskan oleh peneliti.

Selanjutnya, nilai $\mathrm{Q}^{2}$ menunjukkan seberapa baik nilai observasi yang dihasilkan oleh model dan juga estimasi parameternya (Ghozali, 2014). Nilai $Q^{2}$ lebih besar dari nol menunjukkan bahwa model secara keseluruhan memiliki predictive relevance. Berdasarkan nilai perhitungan $\mathrm{R}^{2}$ pada tabel 4.8 , didapatkan hasil $Q^{2}$ sebesar 0,929 melalui perhitungan berikut:

$\mathrm{Q}^{2}=1-\left(1-\mathrm{R}_{1}^{2}\right)\left(1-\mathrm{R}_{2}^{2}\right) \ldots\left(1-\mathrm{R}^{2} \mathrm{x}\right)$

$\mathrm{Q}^{2}=1-(1-0.515)(1-0.695)(1-0.520)$

$\mathrm{Q}^{2}=0.929$

Dari perhitungan di atas didapat nilai $\mathrm{Q}^{2}$ yaitu 0.929 (nilai yang lebih besar dari 0), sehingga menunjukkan bahwa model penelitian layak digunakan.

Tabel 7 menunjukkan bahwa variabel yang paling mempengaruhi kepuasan atas pemulihan jasa adalah interactional justice karena variabel ini memiliki hubungan langsung terkuat dengan nilai $f^{2}$ 0.369 . Sedangkan, hubungan langsung terhadap kepuasan atas pemulihan jasa terlemah dimiliki oleh variabel procedural justice dengan nilai $f^{2} 0.224$. Kemudian, hubungan langsung antara variabel kepuasan atas pemulihan jasa terhadap brand reliability 
dan brand intention keduanya juga kuat. Jika dilihat dari nilai hubungan tidak langsung semua variabel independen diperkuat pengaruhnya terhadap variabel dependen dengan varibael mediasi. Jadi, dapat dilihat bahwa variabel kepuasan atas pemulihan jasa merupakan variabel mediasi yang baik bagi hubungan antara ketiga variabel independen (distributive justice, procedural justice, interactional justice) terhadap kedua variabel dependen (brand reliability dan brand intention).

Tabel 7. Total Effect Variabel-Variabel Independen terhadap Variabel Mediasi \& Variabel Mediasi terhadap Variabel Dependen

\begin{tabular}{ccccccc}
\hline \multirow{2}{*}{$\begin{array}{c}\text { Varia- } \\
\text { bel }\end{array}$} & \multicolumn{2}{c}{ Dirrect Effect } & \multicolumn{2}{c}{ Indirrect Effect } & $\begin{array}{c}\text { Kesim- } \\
\text { pulan }\end{array}$ \\
\cline { 2 - 7 } & KPJ & \multicolumn{1}{c}{$\boldsymbol{B R}$} & $\boldsymbol{B I}$ & $\boldsymbol{B R}$ & $\boldsymbol{B I}$ & \\
\hline$D J$ & $0.248(\mathrm{~S})$ & & & $0.207(\mathrm{~S})$ & $0.179(\mathrm{~S})$ & $\begin{array}{c}\text { Memper- } \\
\text { kuat }\end{array}$ \\
PJ & $0.224(\mathrm{~S})$ & & $0.186(\mathrm{~S})$ & $0.161(\mathrm{~S})$ & $\begin{array}{c}\text { Memper- } \\
\text { kuat }\end{array}$ \\
$I J$ & $0.369(\mathrm{~K})$ & & & $0.308(\mathrm{~S})$ & $0.266(\mathrm{~S})$ & $\begin{array}{c}\text { Memper- } \\
\text { kuat }\end{array}$ \\
KPJ & & $0.834(\mathrm{~K})$ & $0.721(\mathrm{~K})$ & & & $\begin{array}{c}\text { Memper- } \\
\text { kuat }\end{array}$ \\
\hline
\end{tabular}

\section{Tahap 3: Pengujian Hipotesis}

Pengujian hipotesis dilakukan dengan melihat hasil uji-t melalui proses bootstrapping sebagaimana dapat dilihat pada Gambar 3.

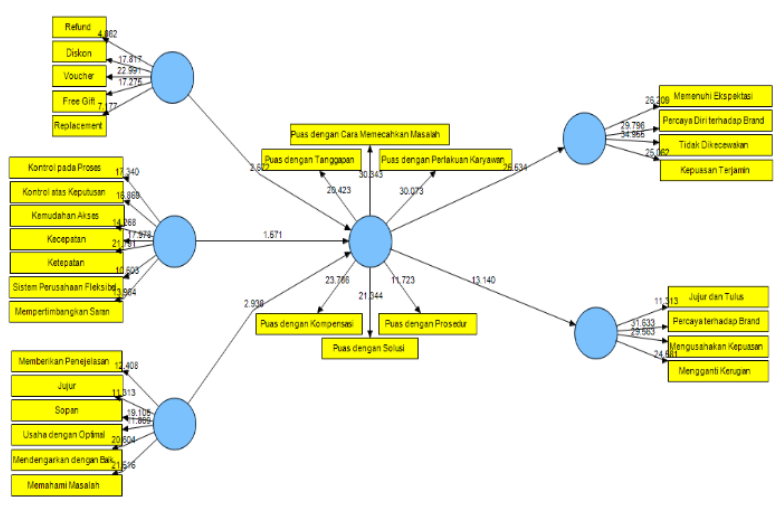

Gambar 3. Ouput Model Hasil Analisis Bootstraping

\section{Pembahasan}

Penelitian ini bertujuan untuk mengetahui apakah pemulihan jasa (distributive justice, procedural justice dan interactional justice) sebagai variabel independen berpengaruh positif dan signifikan terhadap kepercayaan merek (brand reliability dan brand intention) dan kepuasan tamu hotel atas pemulihan jasa sebagai variabel mediasi pada hotel berbintang satu sampai tiga di Indonesia. Data dari 198 responden diolah untuk menganalisa hubungan antar konsep yang diukur. Tabel 9 memperlihatkan kesimpulan hasil pengujian hipotesis.

1. Pengaruh antara pemulihan jasa (distributive justice, procedural justice dan interactional justice) terhadap kepuasan atas pemulihan jasa Hasil penelitian menunjukkan bahwa dari ketiga bentuk pemulihan jasa yang diberikan oleh pihak hotel, hanya distributive justice dan interactional justice yang terbukti secara signifikan mempengaruhi kepuasan atas pemulihan jasa dengan arah hubungan yang positif. Hasil ini mengkonfirmasi penelitian sebelumnya dari Kau dan Loh (2006) yang juga menemukan bahwa hanya distributive justice dan interactional justice yang memiliki hubungan yang positif dan signifikan terhadap kepuasan pelanggan. Dari hasil perhitungan $f^{2}$ di Tabel 8 terlihat bahwa distributive justice dan interactional justice memiliki pengaruh langsung (direct effect) terkuat dengan nilai 0,248 dan 0,369. Distributive justice yang berpengaruh positif dan signifikan mengandung makna bahwa penerapan pemulihan jasa yang dilakukan hotel dengan cara memberikan kompensasi fisikal. Pemberian diskon ketika terjadi kegagalan jasa merupakan indikator yang paling merefleksikan penerapan distributive justice. Bentuk penerapan pemulihan jasa distributive justice merupakan bentuk paling nyata (fisik) yang dapat dirasakan atau dinikmati langsung oleh responden ketika menerima pemulihan jasa. Sehingga, hipotesis pertama poin a yakni distributive justice berpengaruh positif dan signifikan terhadap kepuasan atas pemulihan jasa dapat diterima.

Selanjutnya, variabel procedural justice tidak berpengaruh signifikan terhadap kepuasan tamu hotel atas pemulihan jasa yang disampaikan pihak hotel, sehingga hipotesis terkait hal ini tidak terbukti. Hasil ini berbeda dengan hasil penelitian sebelumnya oleh Kau dan Loh (2006) dimana procedural justice berpengaruh signifikan. Ketidaksesuaian hasil hipotesis variabel procedural justice pada penelitian ini dengan penelitian sebelumnya kemungkinan disebabkan oleh adanya perbedaan karakteristik geografis dan lingkup responden (objek yang diteliti). Penelitian Kau dan Loh (2006) ditujukan kepada masyarakat Singapura dimana partisipan merupakan responden mobile service provider. Dengan perbedaan objek penelitian antara mobile service provider dan hotel maka besar kemungkinan prosedur pemulihan jasa yang diterapkan oleh kedua bisnis jasa juga berbeda. Dalam penelitian Kau dan Loh (2006), 
Tabel 8. Hasil Uji-t (Path Coefficients)

\begin{tabular}{cccrrrrr}
\hline No & Variabel & Variabel ke- & Original Sample & Standar Deviasi & \multicolumn{1}{c}{ T-table } & \multicolumn{1}{c}{ T-Hitung } & \multicolumn{1}{c}{ Kesimpulan } \\
\hline 1 & $D J$ & KPJ & 0.248 & 0.09 & 1.96 & 2.67 & $(+)$ Signifikan \\
2 & $P J$ & KPJ & 0.224 & 0.15 & 1.96 & 1.57 & $(+)$ Tidak Signifikan \\
3 & $I J$ & KPJ & 0.369 & 0.13 & 1.96 & 2.94 & $(+)$ Signifikan \\
4 & KPJ & $B R$ & 0.834 & 0.03 & 1.96 & 25.53 & $(+)$ Signifikan \\
5 & KPJ & $B I$ & 0.721 & 0.06 & 1.96 & 13.14 & $(+)$ Signifikan \\
\hline
\end{tabular}

Tabel 9. Kesimpulan Hipotesis

\begin{tabular}{cccrrr}
\hline Hipotesis ke- & Variabel & Ke-Variabel & Hipotesis Peneliti & Hasil Uji-t & \multicolumn{1}{c}{ Kesimpulan } \\
\hline 1 & $D J$ & KPJ & (+) Signifikan & (+) Signifikan & Terbukti \\
2 & $P J$ & KPJ & (+) Signifikan & (+) Tidak Signifikan & Tidak Terbukti \\
3 & $I J$ & KPJ & (+) Signifikan & (+) Signifikan & Terbukti \\
4 & KPJ & $B R$ & (+) Signifikan & (+) Signifikan & Terbukti \\
5 & KPJ & $B I$ & (+) Signifikan & (+) Signifikan & Terbukti \\
\hline
\end{tabular}

sistem dan prosedur penanganan (kecepatan, ketepakan dan aksesibilitas) serta manajemen dari objek mobile service provider yang diteliti bagi responden memiliki peran sangat penting, karena dalam menangani kegagalan jasa pada mobile service provider, interaksi antar karyawan dengan konsumennya jarang terjadi oleh karena itu dibutuhkan prosedur yang baik sehingga masalah dapat ditangani dengan cepat dan tepat. Berbeda halnya dalam penelitian ini dimana dilakukan pada layanan hotel dimana interaksi antara staf hotel sebagai penyedia jasa dengan tamu cukup intensif. Berpijak pada natur industri hotel inilah maka kemungkinan interaksi personal ketika pemulihan jasa diberikan dinilai lebih penting daripada prosedur yang diterapkan pihak hotel. Ketepatan dalam mengatasi kegagalan jasa merupakan indikator yang paling mampu merefleksikan procedural justice. Dengan demikian, hipotesis pertama poin b yakni procedural justice berpengaruh positif dan signifikan terhadap kepuasan atas pemulihan jasa tidak dapat diterima.

Interactional justice merupakan variabel dari perceived justice yang signifikan mempengaruhi kepuasan responden dengan kontribusi yang paling dominan. Indikator yang paling merefleksikan interactional justice ialah staf hotel yang mendengarkan keluhan tamu dengan baik. Hal ini dapat diartikan bahwa responden pada penelitian ini menilai bahwa komunikasi dan empati oleh pihak hotel dalam proses pemulihan jasa jauh lebih penting daripada kompensasi fisikal (distributive justice). Menurut Singh dan Crisafulli (2015), komunikasi yang berempati dengan melakukan follow-up yang baik ketika melakukan pemulihan jasa ini dapat mengakibatkan emotionally connected antara karyawan dengan konsumen, sehingga konsumen merasa dipahami perasaannya dimana hal ini mengakibatkan kepuasan konsumen. Dengan demikian hipotesis pertama poin c yakni interactional justice berpengaruh positif dan signifikan terhadap kepuasan atas pemulihan jasa dapat diterima.

2. Pengaruh antara kepuasan atas pemulihan jasa sebagai variabel mediasi terhadap kepercayaan merek (brand reliability dan brand intention)

Hipotesis peneliti mengenai pengaruh kepuasan atas pemulihan jasa terhadap kepercayaan merek (brand reliability dan brand intention) dapat diterima. Kepuasan atas pemulihan jasa memiliki pengaruh yang signifikan dan searah (positif) terhadap kedua variabel kepercayaan merek (brand reliability dan brand intention). Apabila dilihat dari nilai skor-loading pada Tabel 4 maka indikator yang paling merefleksikan brand reliability adalah ketika tamu hotela tidak dikecewakan dalam pemulihan jasa. Brand reliability adalah keterandalan sebuah merek hotel kepada konsumennya (Delgado et al., 2003). Pada penelitian ini hasil penghitungan nilai cukup tinggi, yakni nilai $f^{2}$ (direct effect) kepuasan atas pemulihan jasa terhadap brand reliability adalah sebesar 0.834 . Hal ini berarti responden yang puas dengan pemulihan jasa akan memiliki penilaian bahwa merek hotel tersebut dapat diandalkan. Temuan ini mengkonfirmasi Veloutsou (2015) yang menyatakan bahwa kepuasan mendorong timbulnya kepercayaan terhadap merek yang konsumen berikan. Artinya, ketika responden puas dan mendapatkan apa yang diharapkan dari pihak hotel dalam menangani kegagalan jasa, disitulah kredibilitas dan komitmen dari suatu perusahaan dapat dipertanggung jawabkan kepada konsumen (Komunda dan Osarenkhoe, 2012). Dengan demikian, hipotesis kedua poin a yakni kepuasan atas pemulihan jasa berpengaruh positif dan signifikan terhadap brand reliability dapat diterima. 
Kepuasan atas pemulihan jasa memiliki pengaruh yang signifikan dan searah terhadap brand intention. Sebagaimana dinyatakan oleh Delgado et al. (2003) brand intention ini merupakan variabel untuk mengukur kepercayaan merek konsumen. Dari hasil kesimpulan pada Tabel 7 dapat diindikasikan bahwa responden yang puas akan melakukan re-purchase atau mau kembali lagi ke hotel yang sudah melakukan pemulihan jasa yang sesuai dengan harapan konsumen. Indikator yang paling mampu merefleksikan brand intention adalah ketika tamu bisa kembali percaya terhadap brand. Hal ini dapat dibuktikan dari hasil penghitungan nilai $f^{2}$ (direct effect) pada Tabel 8 yang mengukur pengaruh antara kepuasan atas pemulihan jasa terhadap brand intention yakni sebesar 0.721 . Nilai R-square sebesar 0.520 pada brand intention memiliki arti bahwa brand intention muncul sebagai akibat dari variabel kepuasan atas pemulihan jasa sebesar $52 \%$. Hal ini berarti kepuasan responden atas pemulihan jasa berperan penting untuk menentukan brand intention reponden. Hal ini mengkonfirmasi pula studi yang dilakukan oleh Kim et al. (2012) bahwa ketika pihak penyedia jasa mau berusaha mengorbankan serta berkomitmen dalam melakukan pemulihan jasa untuk memenuhi apa yang dibutuhkan konsumen setelah mengalami kegagalan jasa, maka konsumen akan puas. Dengan demikian, hipotesis kedua poin b yakni kepuasan atas pemulihan jasa berpengaruh positif dan signifikan terhadap brand intention dapat diterima. Variabel brand reliability dan brand intention mendukung hipotesis peneliti dimana saat tamu hotel merasa puas atas pemulihan jasa, maka tamu dapat memiliki kepercayaan merek hotel kembali. Sedangkan untuk indikator yang paling menjelaskan variabel kepuasan atas pemulihan jasa ialah ketika tamu puas dengan cara pihak hotel memecahkan masalah.

3. Kepuasan atas pemulihan jasa sebagai variabel mediasi yang signifikan bagi pemulihan jasa (distributive justice, procedural justice dan interactional justice) terhadap kepercayaan merek. Berdasarkan data pada Tabel 8 dapat disimpulkan bahwa secara keseluruhan kepuasan atas pemulihan jasa sebagai variabel mediasi memperkuat hubungan antara ketiga variabel independen (distributive justice, procedural justice dan interactional justice) terhadap kepercayaan merek (brand reliability dan brand intention). Nilai $f^{2}$ (indirect effect) dari pemulihan jasa (distributive justice, procedural justice dan interactional justice) memiliki pengaruh dalam kategori "sedang" (yang berarti cukup kuat dengan nilai $f^{2}$ diatas 0.150 ) terhadap kepercayaan merek (brand reliability dan brand intention) jika melalui variabel mediasi kepuasan atas pemulihan jasa. Sehingga, variabel mediasi (kepuasan atas pemulihan jasa) memiliki pengaruh yang signifikan (mampu memediasikan dengan baik) untuk menghubungkan variabel independen dengan variabel dependen dalam penelitian ini.

Oleh karena itu, kepuasan atas pemulihan jasa terbukti merupakan variabel mediasi yang baik dan signifikan bagi pemulihan jasa terhadap kepercayaan merek pada penelitian ini. Hal ini berarti bahwa tanpa adanya rasa puas dari responden atas pemulihan jasa yang diterima, maka responden tidak mungkin memiliki kepercayaan merek kembali terhadap pihak hotel. Dengan demikian, hipotesis ketiga yakni kepuasan atas pemulihan jasa merupakan variabel mediasi yang positif dan signifikan bagi hubungan anatara pemulihan jasa dengan kepercayaan merek dapat diterima.

Secara keseluruhan, dari hasil pembahasan di atas bahwa penerapan pemulihan jasa yakni distributive justice, procedural justice dan interactional justice berpegaruh secara positif terhadap kepuasan tamu atas pemulihan jasa. Hal ini berarti jika pihak hotel menerapkan pemulihan dengan ketiga pendekatan tersebut dengan baik, maka tamu hotel yang mengalami kegagalan jasa akan merasa puas. Dari ketiga pendekatan pemulihan jasa, procedural justice tidak berpengaruh secara signifikan terhadap kepuasan tamu atas pemulihan jasa yang dilakukan. Kepuasan atas pemulihan jasa yang diberikan oleh pihak hotel terbukti memiliki pengaruh yang positif dan signifikan terhadap kepercyaan merek. Hal ini berarti bahwa tamu yang puas terhadap pemulihan jasa yang diberikan ketika terjadi kegagalan jasa masih tetap mau untuk percaya dengan merek hotel serta mau kembali menginap di hotel tersebut.

\section{SIMPULAN DAN SARAN}

Berdasarkan temuan penelitian dan analisis yang telah dilakukan maka dapat ditarik empat kesimpulan sebagai berikut. Pertama, hasil penelitian menunjukkan bahwa penerapan pemulihan jasa melalui distributive justice, procedural justice dan interactional justice terbukti memiliki pengaruh terhadap kepuasan atas pemulihan jasa. Dari ketiganya, distributive justice dan interactional justice signifikan sedangkan procedural justice tidak signifikan berpengaruh terhadap kepuasan atas pemulihan jasa. Meskipun demikian 
penerapan procedural justice tetap memiliki pengaruh yang positif. Sehingga, dapat disimpulkan semakin baik penerapan ketiga variabel independen di hotel bintang 1-3 maka semakin tinggi pula tingkat kepuasan atas pemulihan jasa yang dirasakan tamu. Kedua, kepuasan atas pemulihan jasa dihipotesiskan memiliki hubungan yang positif dan signifikan dengan kepercayaan merek (brand reliability dan brand intention). Didapati bahwa setiap variabel dependen (brand reliability dan brand intention) secara signifikan dipengaruhi oleh variabel kepuasan atas pemulihan jasa. Artinya, semakin puas tamu terhadap pemulihan jasa yang diterima maka, semakin tinggi tingkat jumlah tamu yang mau kembali memberikan kepercayaan mereknya kepada pihak hotel. Ketiga, kepuasan atas pemulihan jasa terbukti berperan sebagai variabel mediasi yang signifikan bagi variabel independen terhadap variabel dependen. Variabel mediasi dalam penelitian ini sangat diperlukan karena ketiga variabel independen tidak dapat memberikan pengaruh secara langsung terhadap variabel dependen. Yang berarti dengan keberadaan variabel mediasi dapat diindikasikan memperkuat pengaruh variabel independen terhadap variabel dependen.

Hasil penelitia ini memberikan implikasi manajerial bagi manajemen hotel secara khusus antara lain, pertama, pihak hotel terutama hotel berbintang satu sampai tiga selaku sebaiknya mengutamakan perilaku yang memberikan empati (interactional justice) dalam proses pemulihan jasa. Saran ini diberikan berdasarkan hasil penelitian yang menunjukkan bahwa responden memberikan tingkat kesetujuan paling tinggi pada keseluruhan indikator yang ada pada variabel interactional justice. Salah satu indikator yang paling dipentingkan oleh responden yakni "pihak hotel mau mendengarkan tamu dengan baik". Oleh karena itu peneliti menganjurkan ketika pihak hotel melakukan proses pemulihan jasa terhadap tamu, pihak hotel diharapkan mau mendengarkan dan memberikan perhatian lebih (empati) untuk kenyamanan tamu. Sementara itu penerapan distributive justice tidak kalah penting yakni dengan memberikan kompensasi. Rata-rata tingkat kesetujuan dari indikator "replacement" yang berarti tamu ingin mendapatkan ganti rugi yang nilainya dianggap sama oleh tamu atas kegagalan jasa yang dialami. Disamping itu meskipun hasil pada procedural justice kurang signifikan dalam mempengaruhi kepuasan tamu dalam penerapan pemulihan jasa, pihak hotel disini tetap diharapkan untuk tetap melakukan proses prosedur yang baik serta meningkatkannya dalam menangani kegagalan jasa, karena hasil nilai rata-rata tingkat kesetujuan responden masih menganggapnya penting dan masih berpengaruh positif jika dilihat dari nilai pengaruh langsung terhadap kepuasan atas pemulihan jasa.

Bagi penelitian selanjutnya, peneliti memberikan tiga saran sebagai berikut. Pertama, ruang lingkup penelitian bisa diperluas sehingga target responden lebih akurat dan tidak berfokus disuatu kalangan tertentu (swastawan dan pelajar/mahasiswa) yang tentunya berdampak pada kurangnya penelitian dalam mempresentasikan kondisi seluruhnya yaitu scope Indonesia. Kedua, diharapkan model penelitian bisa juga diterapkan pada objek yang lain misalnya hotel bintang 4 dan hotel bintang 5 untuk dapat membandingkan hasil dari masing-masing objek secara akurat. Ketiga, penyebaran kuisioner offline agar lebih diperbanyak penyebarannya dibanding kuisioner online, dikarenakan peneliti tentu akan lebih akurat dalam memilih responden yang sesuai dengan batasan penelitiannya sehingga sampling-error yang terjadi juga lebih rendah. Selain itu, akan ada interaksi langsung antara peneliti dengan responden sehingga, responden akan lebih mudah untuk mengkonfirmasikan dengan peneliti jika ada pernyataan dalam kuisioner yang tidak dipahami. Dalam penelitian ini secara keseluruhan variabel yang digunakan sudah valid dan reliabel, namun demikian pengaruh procedural justice terhadap kepuasan atas pemulihan jasa tidak sebesar sub-variabel pemulihan jasa lainnya. Penelitian selanjutnya dapat menggali variabel lain yang tidak diukur dalam penelitian ini, misalnya faktor budaya, yang mugkin dapat menjelaskan kepuasan konsumen atas pemulihan jasa dengan

\section{DAFTAR REFERENSI}

Abdillah, W. \& Jogiyanto, H.M. (2015). Partial least square (PLS) - Alternative structural equation modelling (SEM) dalam penelitian bisnis. Yogyakarta: Andi.

Babakus, E., Yavas, U., Karatepe, O.M. \& Avci, T. (2003). The effect of management commitment to service quality on employees' effective and performance outcomes. Journal of the Academy of Marketing Science, 31(3), 272-286.

Badan Pusat Statistik (2016). Statistik hotel dan akomodasi lainnya di Indonesia. Jakarta: PT Citra Mawana Patamaro.

Baghestan, A.G., Hamed. E., Omid, M., and Sasan, T. (2012). The impact of service recovery on customer satisfaction: Case of Iran. Archives Des Scienses, 65(11), 506-514.

Ballester, E.D. \& Munuera, A.J.L. (2005). Does brand trust matter to brand equity? Journal of Product and Brand Management, 14(3), 187-196.

Barnes, A. (2003). How to maintain the trust: A study in banking customer. London: The Expert Press. 
Becerra, E.P. \& Badrinarayanan, V. (2013). The influence of brand trust and brand identification on brand evangelism. Journal of Product \& Brand Management, 22 (5/6), 371-383.

Becker, C. (2000). Service recovery strategies: The impact of cultural differences. Journal of Hospitality and Tourism Research, 24 (4), 356-378

Belaid, S., \& Behi, A.T. (2011). The role of attachment in building consumer-brand relationships: An empirical investigation in the utilitarian consumption context. Journal of Product \& Brand Management, 20(1), 37-47.

Boshoff, C. (2005). Managing service quality: An international journal. Journal of Service Theory and Practice, 15(5), 410-425.

Cheung, F.Y.M. \& To, W.M. (2016). A customerdominant logic on service recovery and customer satisfaction. Management Decision, 54, 25242543.

De Ruyter, K., and Wezels, M. (2000). Customer equity considerations in service recovery: A cross industry perspective. International Journal of Service Industry Management, 11, 91-108.

Delgado, E.B., Munuera, J.A. \& Yague, J.G. (2003). Development and validation of a brand trust scale. International Journal of Market Research, 45(1), 35-53.

Duta, K., Venkatesh, U. \& Parsa, H.G. (2007). Service failure and recovery strategies in the restaurant sector. International Journal of Contemporary Hopitality Management, 19(05), 351-363.

Ghozali, I. (2014). Structural equation modelling metode alternative dengan partial least square (PLS) edisi 4. Semarang: Undip.
Kau, A.K. \& Loh, E.W.Y. (2006). The effect of service recovery on consumer satisfaction: A Comparison between complainants and non-complainant. Journal of Service Marketing, 20(2), 101-111.

Kim, T.T., Yoo, J.J. \& Lee G. (2011). Post-recovery customer relationships and customer partnerships in a restaurant setting. International Journal of Contemporary Hospitality Management, 24, 381-401.

Komunda, M. \& OsarenKhoe, A. (2012). Remedy or cure for service failure? Effects of service recovery on customer satisfaction and loyalty. Business Process Management Journal, 18(1), 82103.

Lewis, B.R. \& Sotiris, S. (2001). Service failure and recovery in retail banking: The customer's perspective. International Journal of Bank Marketing, 19, 34-47.

Lewis, B. R., \& Spyrakopoulos, S. (2001). Service failures and recovery in retail banking: The consumers perspective. International Journal of Banking Marketing, 19, 37-47.

Lovelock, C.H. \& Wright, L.K., (2005). Manajemen pemasaran jasa ( $\left.1^{\text {st }} e d\right)$. Jakarta: Indeks.

Oliver, R.L. (1999). Whence consumer loyalty? Journal of Marketing, 63(5), 33-44.

Singh, J. \& Crisafulli, B. (2016). Managing online service recovery: procedures, justice and customer satisfaction. Journal of Service Theory and Practice, 26 (6), 764-787.

Veloutsou, C. (2015. Brand evaluation, satisfaction and trust as predictors of brand loyalty: The mediator-moderator effect of brand relationships. Journal of Consumer Marketing, 32 (6), 405-421. 